\title{
THE IGARAPÉ BAHIA CU-AU MINERALIZATION, CARAJÁS PROVINCE
}

\author{
FERNANDO HENRIQUE BUCCO TALLARICO ${ }^{1}$, CLAUDINEI GOUVEIA DE OLIVEIRA ${ }^{2}$ \\ AND BERNARDINO RIBEIRO FIGUEIREDO ${ }^{1}$
}

\begin{abstract}
The Igarapé Bahia Cu-Au mineralization is hosted by an Archean, low-grade metavolcano-sedimentary sequence. The orebodies define an ellipsoidal structure and are associated with subvertical breccia units located at the contact between two distinct units of the host sequence. Mineralized breccias include fragments of both footwall and hanging wall, which are cemented by variable amounts of chlorite, siderite, magnetite, chalcopyrite, K-bearing phases and minor U-REE-minerals. Quartz diorite dikes that disrupt the host rocks show a variety of textures, ranging from weakly altered granophyric terms to intensely venulated and brecciated rocks. Hydrothermal alteration of dikes includes propylitization, potassification and local albitization. Based on ore petrology and geochemical data (major elements, REE, oxygen and carbon stable isotopes) it is proposed that the progressive interaction of a hot saline and acid, deep-seated fluid with a low-temperature less saline and oxidizing meteoric solutions is the most likely depositional mechanism of the Igarape Bahia mineralization. The resemblance of the alteration styles of mineralized breccias and dioritic dikes suggest that both have interacted with the same hydrothermal fluid. Thus, the dioritic dikes could have been the source of heat and of magmatic fluids during the final stages of epicrustal emplacement.
\end{abstract}

Keywords: Carajás Province, Igarapé Bahia, copper, gold, uranium, rare earth elements

INTRODUCTION The Carajás Basin (Itacaiúnas Supergroup) is located in northern Brazil, on the eastern border of the Archean Amazon Craton (Docegeo 1988) (Fig. 1). Basement rocks consist of gneiss and migmatite of the Xingú Complex (ca. $2.8 \mathrm{Ga}$ - Machado et al. 1991) and the E-W-trending orthogranulites of the Pium Complex (ca. 3.0 Ga - Rodrigues et al. 1992). The Carajás Basin includes metavolcano-sedimentary rocks, of different metamorphic grades, deposited during Late Archean time (ca. $2.75 \mathrm{Ga}$ - Machado et al. 1991). Sandstone and siltstone of a marine environment (Águas Claras Formation - Araújo and Maia 1991), overlie these rocks. The Carajás Basin was intruded by granitic magmas of distinct ages and compositions. Archean intrusions include granites and diorites of the Plaquê Suite (ca. $2.74 \mathrm{Ga}$ - Huhn et al. 1999) and younger alkaline granites (ca. $2.5 \mathrm{Ga}$ ) such as the Estrela Complex (Barros et al. 1992) and the Old Salobo Granite (Machado et al. 1991). Paleoproterozoic intrusions (ca. $1.88 \mathrm{Ga}$ - Machado et al. 1991) include several anorogenic granitic plutons (e.g. Central Carajás Granite, Cigano Granite).

A striking feature of the Carajás Basin is the large number of $\mathrm{Cu}$ $\mathrm{Au}$ mineralizations that are stratigraphically and tectonically related. These are collectively known as the Carajás Copper-Gold Belt, including the Igarapé Bahia Deposit. The proposed genetic models for the Igarapé Bahia Deposit are: (a) syngenetic, volcanic-associated or Besshi-type deposits (e.g. Ferreira Filho 1985, Almada 1998), (b) hydrothermal $\mathrm{Fe}$-oxide $\mathrm{Cu}$-Au-(U-REE) mineralization (e.g. Huhn 1996, Tallarico 1996, Tazava 1999), (c) epigenetic mineralization related to anorogenic Proterozoic granitic plutons (e.g. Lindenmayer $e t$ al. 1998) and (d) multistage genesis involving remobilization of primary Archean mineralization during Proterozoic time (e.g. Ribeiro 1989).

The purpose of this work is to present the diagnostic geological attributes, i.e. the descriptive model (Barton 1993) of the Igarapé Bahia primary mineralization. The present study includes the results of fieldwork, petrography, geochemistry (including REE, oxygen and carbon stable isotopes) and mineralogical investigation by XRD, SEM and EMPA. Finally, the data are modelled to investigate the fluid constraints and discuss the genetic alternatives.

GEOLOGY OF THE IGARAPÉ BAHIA DEPOSIT The Igarapé Bahia Group The Igarapé Bahia Deposit is hosted by metavolcano-sedimentary rocks with very low-grade hydrothermalmetamorphic assemblages (Igarapé Bahia Group). Ductile deformation is absent and primary structures and textures are usually preserved. Volcanic rocks including aphanitic, vesicular and microporphyritic

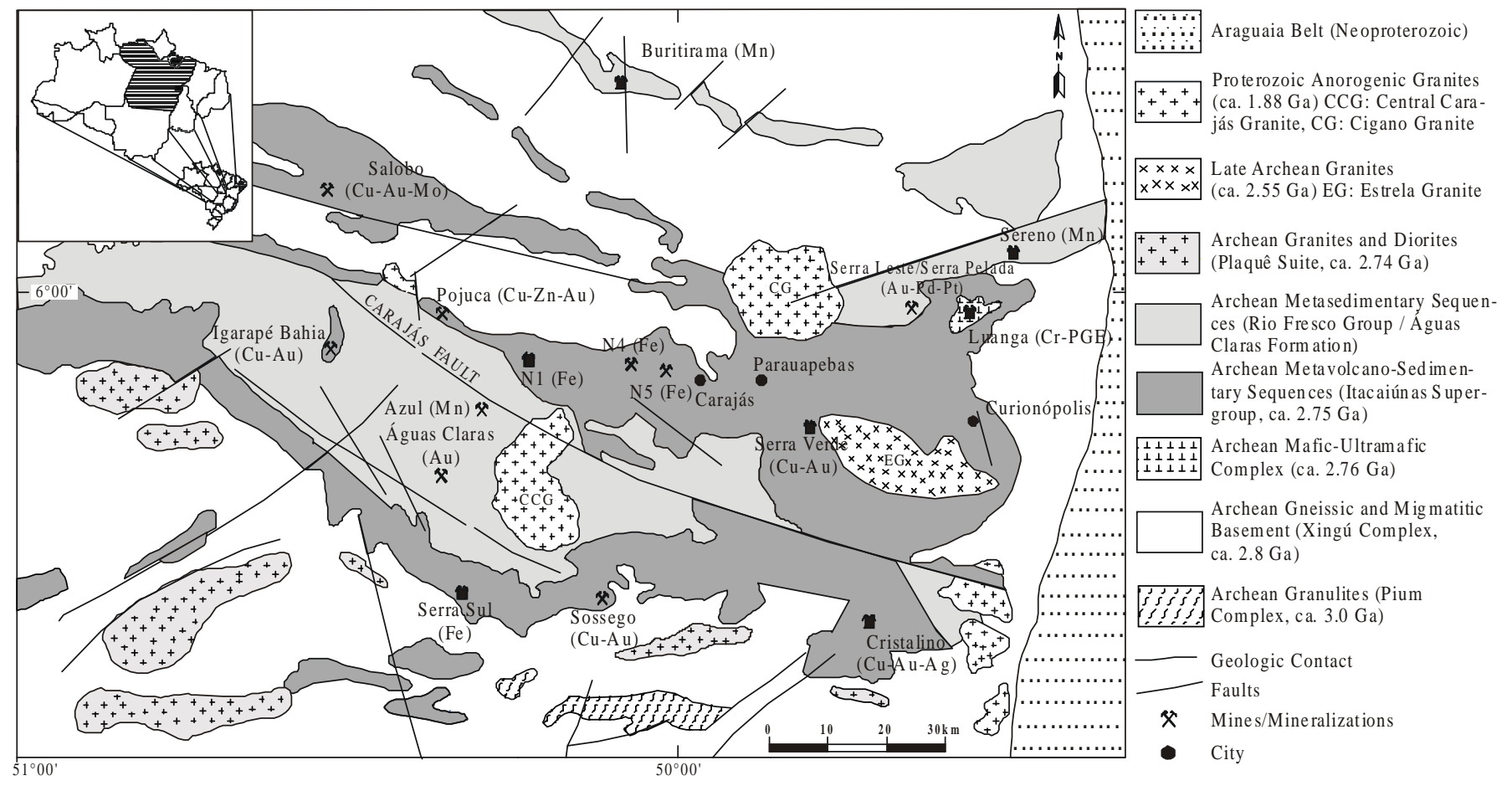

Figure 1-Simplified geological map of the Carajás Copper-Gold Belt (based on Docegeo 1988, Araújo and Maia 1991, Barros and Barbey 1998).

1 - Instituto de Geociências, Universidade Estadual de Campinas, Cx. Postal 6152, 13083-970, Campinas, SP. fernando@ige.unicamp.br, berna@ige.unicamp.br.

2 - Instituto de Geociências, Universidade de Brasília, Campus Universitário Darcy Ribeiro, Asa Norte, 70910-900, Brasília, DF. gouveia@unb.br. 


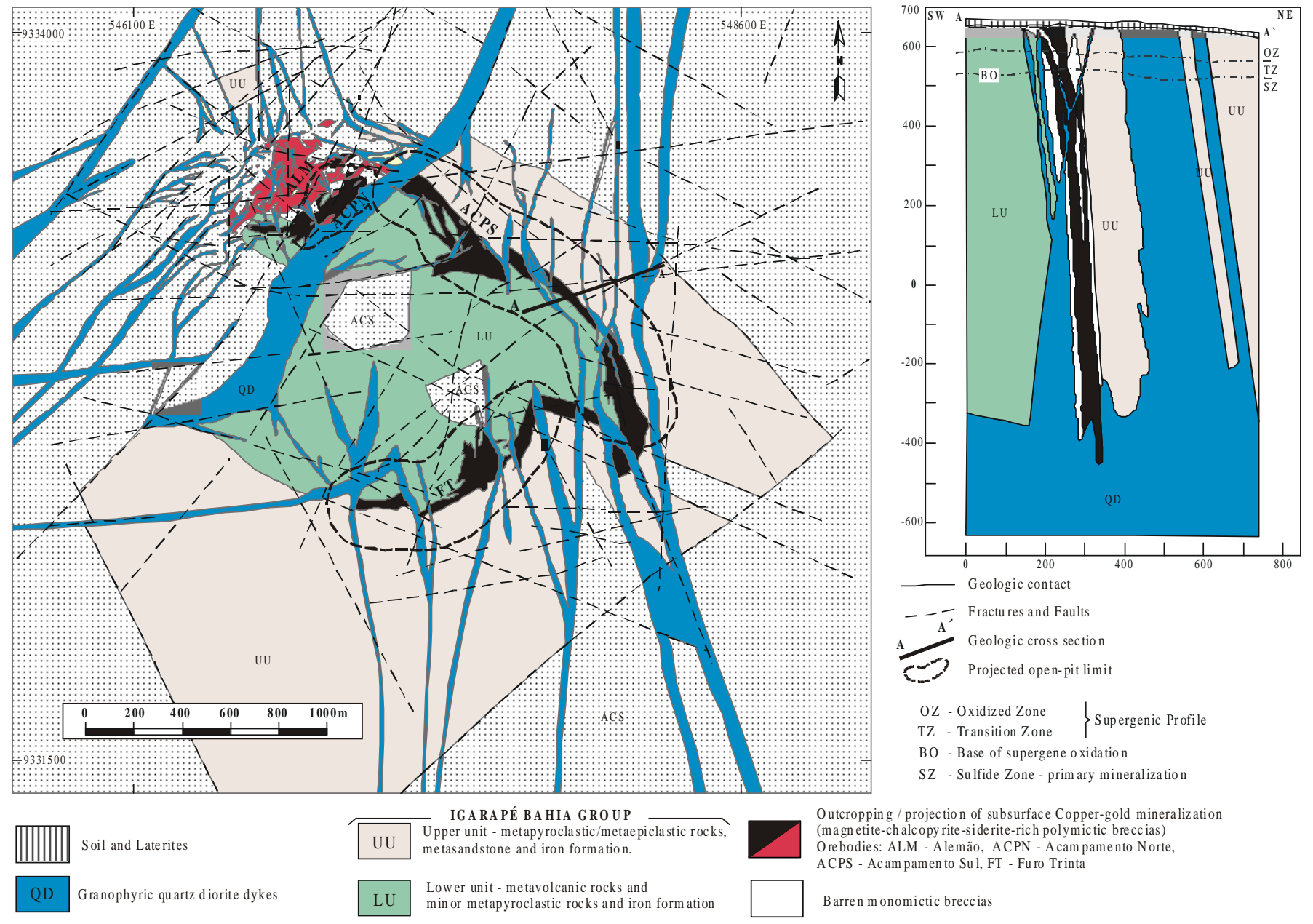

ACS: Águas Claras Formation - metasand stone

Figure 2-Geological map of the Igarapé Bahia Copper-Gold mineralization and geological cross section A-A' through the Acampamento Sul Orebody (modified from CVRD/DOCEGEO 1996, unpublished).

varieties, and minor crystal tuffs and ironstones dominate the lower unit. The upper unit is composed of lithic tuffs, crystal tuffs, laminated epiclastics, ironstone, epiclastic conglomerates and sandstone (Fig. 2).

These rocks display extensive hydrothermal alteration. Primary phases are completely replaced by a mixture of quartz and chlorite. Siderite, chalcopyrite and magnetite occur either disseminated or in veins. Veining of host rocks becomes progressively more intense towards the $\mathrm{Cu}-\mathrm{Au}$ mineralization, eventually with jigsaw textures and breccia development. Laminated epiclastic rocks exhibit stratabound replacement textures with the development of $\mathrm{cm}$-scale chalcopyrite beds and nodules, both connected to stockwork vein systems. The nodules bent the primary bedding and are also transgressive with respect to lamination.

Águas Claras Formation The Igarapé Bahia Group is overlain by sandstone of the Águas Claras Formation. The contact between them is characterized by normal faults. Occasionally the sandstone hosts massive chalcopyrite veins ranging from a few $\mathrm{mm}$ up to $1-\mathrm{m}$ thick.

Quartz diorite dikes A set of fractures and normal faults control the emplacement of quartz diorite dikes, which disrupt the metavolcano-sedimentary rocks and the Águas Claras sandstone. Zones of intense alteration and veining, where apophyses and contact breccias are common, mark the contact between dikes and the host sequence. Chlorite-rich albitites and concentrations of almandine neoblasts in the host rock locally border the apophyses.

Quartz diorite shows a granophyric texture with primary andesine phenocrysts $(\mathrm{An} \sim 30 \mathrm{~mol} \%)$ rimmed by coronas of quartz-albite intergrowth. Matrix includes albite, quartz, and minor K-feldspar and ilmenite. The dikes display hydrothermal alteration of varied intensity. A continuum spectrum including weakly altered to intensely venulated and brecciated rocks is observed. Primary plagioclase is converted to albite + calcite + chlorite + epidote, and ilmenite is oxidized to rutile + magnetite. Secondary K-feldspar, biotite and muscovite are related to potassic alteration. Quartz diorites also host sulfide minerals (chalcopyrite and rare pyrite, galena, sphalerite and molybdenite) either disseminated or in veins. Uraninite and REE-minerals (monazite, apatite, xenotime, and parisite) are associated with the alteration of the diorite dikes.

\section{THE COPPER-GOLD MINERALIZATION}

The host metavolcano-sedimentary sequence together with the Furo Trinta (FT), Acampamento Sul (ACPS) and Acampamento Norte (ACPN) Orebodies outcrop in a structural window surrounded by the Águas Claras Sandstone. The outcropping orebodies define a semicircular structure at the surface. Although covered by a discordant layer of sandstone, the Alemão (ALM) Orebody also integrates this structure at depth and is connected to the ACPN Orebody by way of normal faults (Soares et al. 1999). The orebodies consist of steeply dipping $\left(\sim 75^{\circ}\right)$ $\mathrm{Cu}$-Au-bearing breccias located at the contact zone between the upper (hanging wall) and the lower (footwall) units of the host metavolcanosedimentary sequence. The orebodies dip outward and the strike is concordant with bedding of host rocks.

Breccia types, hydrothermal alteration and veins The $\mathrm{Cu}-\mathrm{Au}$ breccias are essentially polymictic, thus classification was based on matrix mineralogy leading to the following groups: chlorite breccias, siderite breccias and magnetite breccias. Angular fragments ranging from a few $\mathrm{mm}$ to over $20 \mathrm{~cm}$ in diameter of both footwall and hanging wall are cemented by variable amounts of hydrothermal matrix. Chlorite breccias and siderite breccias exhibit the same matrix mineralogy but the amounts of these specific minerals are distinct. The matrix is fine-grained and includes Fe-chlorite, siderite, magnetite, chalcopyrite, quartz and minor tourmaline. 
Magnetite breccias exhibit a granular matrix of euhedral magnetite in association with $\mathrm{Fe}$-chlorite, $\mathrm{Cu}$-sulfides, siderite, grunerite, quartz, $\mathrm{K}$-feldspar, stilpnomelane, biotite and minor tourmaline, muscovite and fluorite. The association defines a distinctive $\mathrm{Fe}-(\mathrm{K})$-metasomatic zone. Magnetite is stoichiometric and constantly Ti-free.

At the ACPS and FT, mineralization is preferentially related to siderite breccias, while at the ACPN and ALM, it is associated with magnetite breccias. Chlorite breccias broadly occur at the margins of all orebodies and are also mineralized.

Chloritization is the most common and widespread alteration observed. $\mathrm{Mg}$-chlorite $(50>m g>30)$ is typically associated with calcite, dolomite and quartz in barren and distal altered host rocks, while Fechlorite $(30>m g>12)$ is paragenetic to siderite and magnetite in $\mathrm{Cu}-$ Au-bearing breccias $\left(m g=100 \mathrm{Mg} /\left[\mathrm{Mg}+\mathrm{Fe}_{\text {tot }}\right]\right.$, in cation per unit formula). In this work chlorite thermometry (Cathelineau 1988) was calculated for a variety of rocks. The calculated mean temperatures are: $321^{\circ} \mathrm{C}$ for altered metavolcanic rocks, $339^{\circ} \mathrm{C}$ for chlorite breccias, $321^{\circ} \mathrm{C}$ for magnetite breccias, $375^{\circ} \mathrm{C}$ for siderite breccias, $313^{\circ} \mathrm{C}$ for altered quartz diorites and $369^{\circ} \mathrm{C}$ for chalcopyrite nodules from host rocks.

Several vein types crosscut the breccias and the host rocks. Veins are usually discordant to bedding and occasionally exhibit comb structures. The most frequent varieties are: (a) calcite + chalcopyrite \pm fluorite \pm stilpnomelane, (b) ankerite \pm chalcopyrite \pm gold, (c) siderite + calcite + quartz + chlorite + chalcopyrite, and (d) chalcopyrite \pm biotite \pm K-feldspar \pm tourmaline \pm REE-minerals. Vein chronology is unknown due to the recurrences and unclear crosscut relations.

Ore mineralogy Hypogene copper mineralization consists of chalcopyrite and traces of chalcocite, digenite and covellite that occur as rims on chalcopyrite in grain boundary driven oxidation reactions. Magnetite breccias, unlike other breccias, include chalcopyrite intergrown with bornite, indicating a relatively higher oxidation state of the fluid. Traces of pyrite are observed as inclusions in chalcopyrite as a function of local sulfur excess. The major copper mineralization is juxtaposed to gold mineralization in all orebodies. Additional, subeconomic copper concentration occurs in veins, nodules or disseminated in marginal altered host rocks with negligible gold content. Native gold occur as fine particles, usually between 5 to 20 $\mathrm{mm}$, included in gangue minerals (quartz, siderite and chlorite), chalcopyrite and occasionally in magnetite. Silver is a byproduct occurring as hypogene $\mathrm{Au}-\mathrm{Ag}$ alloy (up to $12 \mathrm{wt} \% \mathrm{Ag}$ ), hessite $\left(\mathrm{Ag}_{2} \mathrm{Te}\right)$ and argentite/acanthite $\left(\mathrm{Ag}_{2} \mathrm{~S}\right)$.

Supergene alteration and related ore types At the Igarapé Bahia Deposit weathering is responsible for the development of a thick oxidized profile, where gold and copper are segregated and reconcentrated leading to the formation of different ore-types. The oxidized zone extends from surface to 150 -m depth. It constitutes a gold-bearing gossan (total reserves in December 1999 of $18.5 \mathrm{Mt} \cong$ $1.97 \mathrm{gAu} / \mathrm{t}$ ) from which approximately $11 \mathrm{t}$ Au per year are mined. Total Au production is $c a$. $60 \mathrm{t}$ to the present. The gossanous transition zone occurs from 150- to 200-m depth, where supergene solutions have percolated and precipitated metals, originating a secondary $\mathrm{Cu}-$ $\mathrm{Au}$ ore $(9.5 \mathrm{Mt} \cong 2.45 \mathrm{gAu} / \mathrm{t}, 3.83 \mathrm{wt} \% \mathrm{Cu})$. The hypogene $\mathrm{Cu}-(\mathrm{Au})$ mineralization $(219 \mathrm{Mt} \cong 0.86 \mathrm{gAu} / \mathrm{t}, 1.4 \mathrm{wt} \% \mathrm{Cu})$ occurs beneath 200-m depth.

Ore Geochemistry The mineralized breccias contain anomalous concentrations of $\mathrm{FeO}_{\mathrm{T}}(25-64 \mathrm{wt} \%), \mathrm{Cu}(0.5-11 \mathrm{wt} \%), \mathrm{U}(28-380$ ppm), Au (0.5-15 ppm), Ag (4-52 ppm), Ba (26-200 ppm), F (390$31000 \mathrm{ppm}), \mathrm{P}(900-6200 \mathrm{ppm})$ and REE, particularly La (260-2300 $\mathrm{ppm})$ and $\mathrm{Ce}(450-4400 \mathrm{ppm})$. Breccias are also enriched in $\mathrm{MnO}$ (0.5-3 wt \%), $\mathrm{CaO}(0.5-9 \mathrm{wt} \%)$, Mo (50-200 ppm) and $\mathrm{Zn}(150-450$ $\mathrm{ppm}$ ) relatively to host rocks. The intercorrelated behavior of all these elements suggests a common metasomatic origin and reflects the interplay of Fe-metasomatism, sulfidation, chloritization and carbonate alteration. Traces of barite, fluorite, galena, altaite, sphalerite, molybdenite, uraninite, apatite, monazite, xenotime, bastnäsite and parisite as inclusions in chalcopyrite and gangue minerals account for the $\mathrm{Ba}, \mathrm{F}, \mathrm{Pb}, \mathrm{Zn}, \mathrm{Mo}$, U, REE and $\mathrm{P}$ enrichment. The high manganese content is related to siderite, which contains up to $7 \mathrm{wt} . \% \mathrm{MnO}$.

The REE-distribution patterns of breccias are similar for different types, and show a strong enrichment in LREE (Fig. 3). Distribution patterns of the metavolcanic rocks, dioritic dikes and breccias show equivalent shape, but the absolute concentrations are quite distinct. Iron formations show a completely distinct pattern. REE minerals are unequivocally related to hydrothermal activity. Thus, rather than reflecting petrologic information concerning the primary system(s), REE patterns are suitable to monitor the intensity of the hydrothermal alteration. The contrasting $\mathrm{La} / \mathrm{Lu}$ ratios of host metavolcanic rocks (70-250) and breccias (1000-2500) indicate the preferential concentration of LREE by the hydrothermal solution(s). Additionally, the similarity between the distribution patterns of altered metavolcanic rock, breccias and diorite dikes suggests that these rocks underwent a common alteration process.

Stable isotope analyses were performed in calcite and siderite from veins and matrix of mineralized breccias (Oliveira et al. 1998). Carbon isotopes yield a narrow range of $\delta^{13} \mathrm{C}(-9.3$ to $-5.8 \%$ ), while oxygen isotopes presented a wider variation of $\mathrm{d}^{18} \mathrm{O}(0.7$ to $9.4 \%$ ) $)$. The results are plotted in Fig. 4, comparatively to other well-known reservoirs.

DISCUSSION The results of chlorite geothermometry, that yielded a range between $313-375^{\circ} \mathrm{C}$ for the Igarapé Bahia hydrothermal system, are in accordance with previous fluid inclusion homogenization temperatures of Ribeiro (1989) and Lindenmayer et al. (1998). The equilibrium gold-hessite provides additional support for this thermal range (Markham 1960).

According to the thermodynamic calculations of Mickucki and Ridley (1993), the equilibrium siderite-magnetite-chalcopyrite \pm bornite, at $300^{\circ} \mathrm{C}$ and $2 \mathrm{kbar}$, indicates high $f \mathrm{O}_{2}\left(10^{-29}\right.$ to $\left.10^{-31}\right)$ and low $\mathrm{a}_{\mathrm{SS}}\left(\mathrm{a}_{\mathrm{SS}} \sim 10^{-3}\right)$ for the Igarapé Bahia hydrothermal system. At greenschist temperatures and high $\mathrm{CO}_{2}$ content, $\mathrm{Fe}$-oxides equilibrate with siderite instead of minnesotaite/greenalite, with grunerite being stable only at upper greenschist and amphibolite temperatures (Frost 1979). Thus, the equilibrium siderite-magnetite (ACPS and FT) indicates a distinctively high $\mathrm{CO}_{2}$ content in the fluid in relation to magnetite breccias, while the pair grunerite-magnetite (ALM and ACPN) denotes relatively higher temperatures. The inferred $\mathrm{CO}_{2}$ enrichment of fluid phases is supported by the fluid inclusion data of Almada (1998) who reported aqueous, aqueous-carbonic and carbonic compositions.

The calculated thermal range coupled with the high $\mathrm{fO}_{2}$ of the Igarapé Bahia hydrothermal system are consistent with $\mathrm{Cu}$ and $\mathrm{Au}$ transport via Cl-complexes, which are active in acid, saline and oxidizing fluids (Davidson and Large 1994). In high-temperature, saline and acid solutions, REE and $U$ are complexed preferentially by chloride with or without the competition from fluoride, $\mathrm{CO}_{2}$ or phosphorous species depending on the relative abundance of the ligands (Gieré 1996). These ions were clearly active in Igarapé Bahia and promoted a selective concentration of LREE, only possible under acid to neutral conditions (Gieré 1996).

The narrow range of negative values of $\mathrm{d}^{13} \mathrm{C}$ together with the indication of high $\mathrm{fO}_{2}$, denote a homogeneous deep-seated carbon source from which carbonate minerals were precipitated with limited $\mathrm{pH}$ variations. The wider range of $\mathrm{d}^{18} \mathrm{O}$ values is interpreted as resulting from the mixture of deep-seated solutions with meteoric fluids that respectively account for the high and low $\mathrm{d}^{18} \mathrm{O}$ values. This fluid mixing hypothesis is in agreement with previous fluid inclusion studies of the Igarapé Bahia hydrothermal system that demonstrated the existence of two distinct groups: (a) $150-430^{\circ} \mathrm{C}$ and up to $40 \%$ $\mathrm{NaCl}_{\text {eq }}$ and (b) $100-150^{\circ} \mathrm{C}$ and $\sim 10 \% \mathrm{NaCl}_{\text {eq }}$ (e.g. Ribeiro 1989 , Lindenmayer et al. 1998). Stable isotope and fluld inclusion data, both

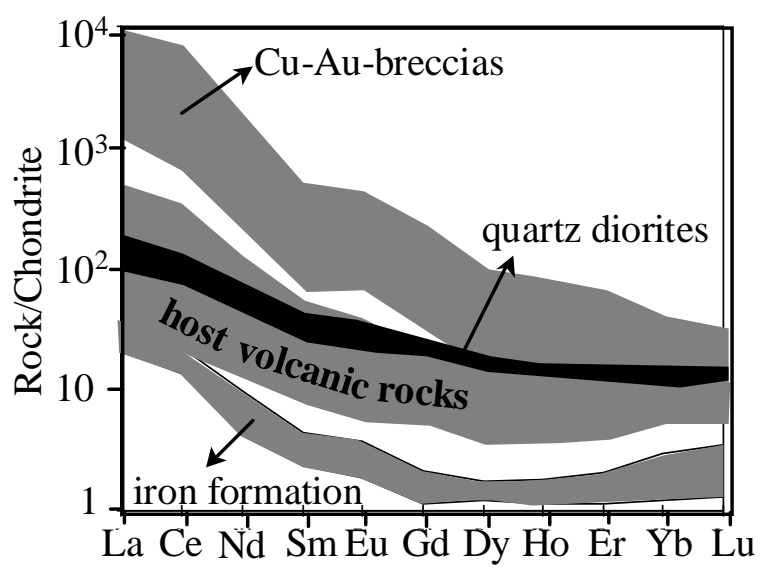

Figure 3-Chondrite normalized REE patterns of mineralized breccia, host metavolcanic rocks and banded iron formations from the Igarapé Bahia Deposit. Chondrite composition according to Evensen et al. (1978). 
suggest that the progressive interaction of a hot saline and acid magmatic fluid with a low-temperature oxidizing and less saline meteoric solutions is the most likely depositional mechanism of the Igarapé Bahia ore. Persistent fluid mixing over a focused heat source possibly triggered $\mathrm{Cu}, \mathrm{Au}, \mathrm{U}$ and REE deposition through $f \mathrm{O}_{2}$ and temperature decrease and $\mathrm{pH}$ increase.

At deposit scale, primary structures are preserved and ductile elements such as lineation, foliation and satellite folds were not observed. Brittle deformation is extensive and includes fractures and normal faults. Map analysis together with the outward dip of the bedding suggest that the structural framework of the Igarape Bahia Deposit resulted from pluton emplacement that caused roof uplifting and lateral shouldering of wall rocks along faults. These brittle processes are typically related to near surface plutons (Paterson et al. 1991). The resemblance of the alteration styles of mineralized breccias and

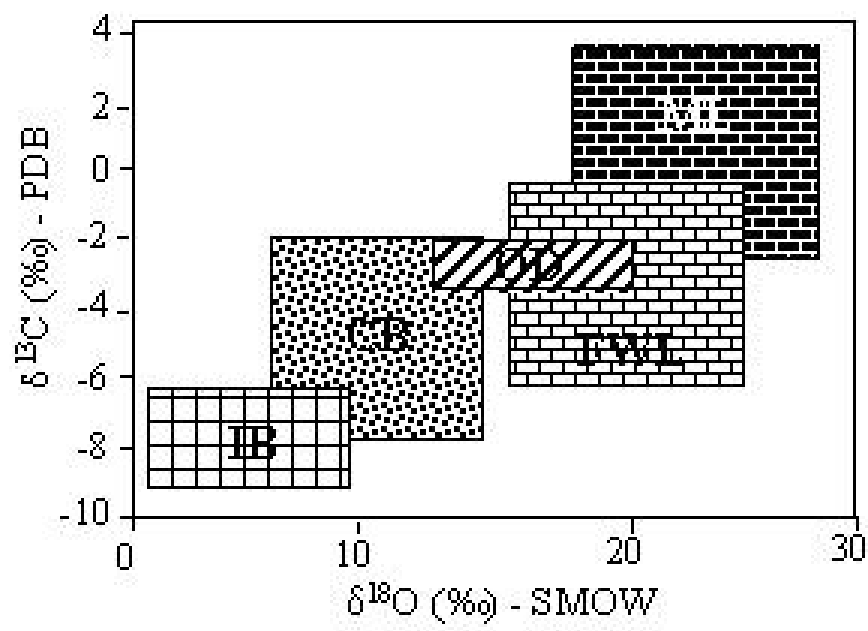

Figure $4-\delta^{13} C v s . \delta^{18} O$ diagram showing the isotopic composition of siderite and calcite from the Igarapé Bahia mineralization $(I B)$, relative to carbonatites $(C B)$, the Olympic Dam mineralization $(O D)$, freshwater limestone $(F W L)$ and marine limestone $(M L)$. Fields for $C B, O D, F W L$ and ML after Oreskes and Einaudi (1992). dioritic dikes suggest that both have interacted with the same hydrothermal fluid. Thus, the dioritic dikes could have been the source of heat and magmatic fluids during the latest stages of epicrustal emplacement.

The origin of the stratabound morphology of the Igarapé Bahia orebodies remains a matter of debate. One could speculate that it derives from primary exhalative processes or from epigenetic stratabound replacement and brecciation. The brecciation and veining of both footwall and hanging wall, together with the presence of sub-economic chalcopyrite concentrations in the Águas Claras sandstone, suggest an epigenetic origin.

The alteration styles, ore mineralogy and fluid composition of the Igarapé Bahia Deposit are analogous to other intrusion-related hydrothermal Fe-oxide-(Cu-Au-U-REE) deposits (Hitzman et al. 1992). On the other hand, the confinement of all known mineralizations of the Carajás Copper-Gold Belt to the Itacaiúnas metavolcano-sedimentary sequences suggests that primary processes could have pre-concentrated metals. Thus, a multi-stage genesis involving the superposition of Archean exhalative processes and further hydrothermal-magmatic activity seems plausible. Mellito (1998) documented a similar process at Salobo, where Archean syngenetic mineralization was reconcentrated during the Late Archean time due to tectonic and magmatic activity.

The composition of the dikes favors an Archean age for the magmatic activity at Igarapé Bahia, since the dioritic magmatism in the region is bracketed within the interval of 2.55 to $2.74 \mathrm{Ga}$. Additional support is provided by the $\mathrm{Rb}-\mathrm{Sr}$ bulk-rock age of 2,577 $\pm 2 \mathrm{Ma}$ of the Igarapé Bahia host metavolcanic rocks (Ferreira Filho 1985). This age is inconsistent with the minimum age of $c a .2 .6 \mathrm{Ga}$ of the overlying Águas Claras Sandstone (Dias et al. 1996), and may indicate thermal resetting of the $\mathrm{Sr}$ isotopic system during the emplacement of Late Archean (ca. $2.55 \mathrm{Ga})$ intrusions.

Acknowledgments To the Companhia Vale do Rio Doce for the permission to publish their private data. The authors are thankful to all the geologists of the Igarapé Bahia mine, especially José Luzimar Rego for enthusiastic discussions during fieldwork. We acknowledge the referees of RBG and also all the anonymous reviewers that improved our original manuscript. We are also indebted to FAPESP (Fundação de Amparo à Pesquisa do Estado de São Paulo) for the grants \#98/ 14401-5 and \#99/03058-0. We are thankful to the Multi User SEM laboratory (IG-UNICAMP) funded by FAPESP grant \#95/06401-7.

\section{References}

Almada M.C.O. 1998. O corpo Acampamento Sul do depósito Bahia, Carajás: características geológicas e fluidos hidrotermais. Centro de Geociências, UFPA, Belém, MSc Dissertation, $99 \mathrm{p}$.

Araújo O.J.B, Maia R.G.N. 1991. Serra dos Carajás, folha SB.22-Z-A, Estado do Pará. Brasília, DNPM, 136p. (Programa Levantamentos Geológicos Básicos do Brasil)

Barros C.E.M., Barbey P. 1998. A importância da granitogênese tardi-arqueana (2.5 Ga) na evolução tectono-metamórfica da Província Mineral de Carajás - Complexo evolução tectono-metamórfica da Província Mineral de Carajás - Complexo 28:513-522

Barros C.E.M., Dall'Agnoll R., Lafon J.M., Teixeira N.P., Ribeiro J.W. 1992. Geologia geocronologia Rb-Sr do Gnaisse Estrela, Curionópolis, PA. Boletim do Museu Paraense Emílio Goeldi, Ciências da Terra, 4:83-104

Barton P.B. 1993. Problems and opportunities for mineral deposit models. In: R.V. Kirkham W.D. Sinclair; R.I. Thrope; J.M. Duke (eds.) Mineral Deposit Modeling. Geological Association of Canada, Special Paper 40, 7-13

Cathelineau M. 1988. Cation site occupancy in chlorites and illites as a function of temperature. Clay Minerals, 23:471-485

Davidson G.J, Large R.R. 1994. Gold metallogeny and the copper-gold association of Australian Proterozoic. Mineralium Deposita, 29:208-223

Dias G.S., Macambira M.J.B., Dall'Agnol R., Soares A.D.V., Barros C.E.M. 1996. Datação de zircões de sill de metagabro: comprovação da idade arqueana da Formação Águas
Claras, Carajás, Pará. In: SBG, Simpósio de Geologia da Amazônia, 5, Belém, ReClaras, Carajás, Pará. In: SBG,
sumos Expandidos, 376-379

DOCEGEO (Rio Doce Geologia e Mineração S.A.). 1988. Província Mineral de Carajás. Litoestratigrafia e principais depósitos minerais. In: SBG, Congresso Brasileiro de Geologia, 35, Belém, Anexo aos Anais, 165p.

Evensen N.M., Hamilton P.J., O'Nions R.K. 1978. Rare-earth abundance in chondritic meteorites. Geochim. Cosmochim. Acta, 42:1199-1212

Ferreira Filho, C.F. 1985. Geologia e mineralizações sulfetadas do Prospecto Bahia, Pro víncia Mineral de Carajás. Instituto de Geociências, Universidade de Brasília, Brasília, MSc Dissertation, 112p.

Frost B.R. 1979. Metamorphism of iron-formation: paragenesis in the system Fe-Si-C-O-H. Economic Geology, 74:775-785

Gieré R. 1996. Formation of rare earth minerals in hydrothermal systems. In: A.P. Jones; F. Wall; C.T. Williams (eds.) Rare Earth Minerals. London, Chapman \& Hall, 105-150

Hitzman M.W., Oreskes N., Einaudi M.T. 1992. Geological characteristics and tectonic setting of Proterozoic iron oxide (Cu-U-Au-REE) deposits. Precambrian Research, setting of P1 $241-287$

Huhn S.R.B. 1996. São os depósitos cupríferos de Carajás do tipo Cu-Au-U-ETR? In: SBG Simpósio de Geologia da Amazônia, 5, Belém, Resumos Expandidos, 140-143

Huhn S.R.B., Macambira M.J.B., Dall' Agnol R. 1999. Geologia e geocronologia Pb/Pb do granito alcalino Arqueano Planalto, Região da Serra do Rabo, Carajás - PA. In: SBG, Simpósio de Geologia da Amazônia, 6, Manaus, Resumos Expandidos, 463-466
Lindenmayer, Z.G.; Ronchi, L.H.; Laux, J.H. 1998. Geologia e geoquímica da mineralização de $\mathrm{Cu}-\mathrm{Au}$ primária da mina de Au do Igarapé Bahia, Serra dos Carajás. Revista Brasileira de Geociências, 28:257-268

Machado N., Lindenmayer Z, Krogh T.E., Lindenmayer D. 1991. U-Pb geochronology of Archean magmatism and basement reactivation in the Carajás area, Amazon Shield, Brazil. Precambrian Research, 49:329-354

Markham N.L. 1960. Synthetic and natural phases in the system Au-Ag-Te, Part I. Economic Geology, 55:1148-1178

Mellito K.M. 1998. Aplicações dos sistemas $\mathrm{Rb}-\mathrm{Sr}, \mathrm{Pb}-\mathrm{Pb}$ e Sm-Nd no depósito polimetálico do Salobo 3 A, Província Mineral de Carajás, Pará. Inst. Geociências, USP, São Paulo, MSc Dissertation, 113p.

Mikucki E.J. \& Ridley J.R. 1993. The hydrothermal fluids of Archean lode-gold deposits at different metamorphic grades: compositional constraints from ore and wallrock alteration assemblages. Mineralium Deposita, 28:469-481

Oliveira C.G., Tazava E., Tallarico F.H.B., Santos R.V., Gomes C. 1998. Gênese do depósito de Au-Cu-(U-ETR) de Igarapé Bahia, Província Mineral de Carajás. In: SBG, Congresso Brasileiro de Geolologia, 40, Belo Horizonte, Anais, 137

Oreskes N. \& Einaudi, M.T. 1992. Origin of hydrothermal fluids at Olympic Dam: preliminary results from fluid inclusions and stable isotopes. Economic Geology, 87:64-90

Paterson S.R., Vernon R.H., Fowler T.K. 1991. Aureole tectonics. In: D.M. Kerrick (ed.) Contact Metamorphism. Min. Soc. America, Reviews in Mineralogy, Volume 26 , 673-722

Ribeiro A.M.R. 1989. Estudo geoquímico do sistema hidrotermal relacionado à mineralização cuprífera da Area Bahia, Serra dos Carajás, Pará. Centro de Geociências, UFPA, Belém, MSc Dissertation, 134p.

Rodrigues E.S., Lafon J.M., Scheller T. 1992. Geocronologia Pb-Pb da Província Mineral de Carajás: primeiros resultados. In: SBG, Congresso Brasileiro de Geologia, 37, São Paulo, Resumos Expandidos, 2:183-184

Soares A.D.V., Ronzê P.C., Santos M.G.S., Leal E.D., Barreira C.F. 1999. Geologia e mineralizações do depósito de Cu-Au Alemão - Província Mineral de Carajás (PA). SBG, Simpósio de Geologia da Amazônia, 6, Manaus, Anais, 144-147

Tallarico F.H.B. 1996. Projeto de revisão do modelo geológico da mina de Igarapé Bahia: petrografia química mineral e litogeoquímica. Belo Horizonte, CVRD (relatório interno), $57 \mathrm{p}$

Tazava E. 1999. Mineralização de Au-Cu-(+ETR-U) associada às brechas hidrotermais do depósito de Igarapé Bahia, Província Mineral de Carajás, PA. Dep. Geologia, UFOP, Ouro Preto, MSc Dissertation, 81p.

Contribution IGC-078

Received February 2,2000

Accepted for publication April 30, 2000 